NATIONAL LABORATORY

MANAGED BY UT-BATTELLE

FOR THE DEPARTMENT OF ENERGY

\title{
Beyond Guaranteed Savings: Additional Cost Savings Associated With ESPC Projects
}

March 2013

Prepared by John Shonder

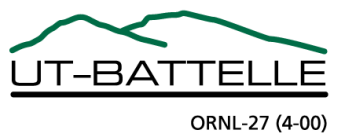




\section{DOCUMENT AVAILABILITY}

Reports produced after January 1, 1996, are generally available free via the U.S. Department of Energy (DOE) Information Bridge.

Web site http://www.osti.gov/bridge

Reports produced before January 1, 1996, may be purchased by members of the public from the following source.

National Technical Information Service

5285 Port Royal Road

Springfield, VA 22161

Telephone 703-605-6000 (1-800-553-6847)

TDD 703-487-4639

Fax 703-605-6900

E-mail info@ntis.gov

Web site http://www.ntis.gov/support/ordernowabout.htm

Reports are available to DOE employees, DOE contractors, Energy Technology Data Exchange (ETDE) representatives, and International Nuclear Information System (INIS) representatives from the following source.

Office of Scientific and Technical Information

P.O. Box 62

Oak Ridge, TN 37831

Telephone 865-576-8401

Fax 865-576-5728

E-mail reports@osti.gov

Web site http://www.osti.gov/contact.html

This report was prepared as an account of work sponsored by an agency of the United States Government. Neither the United States Government nor any agency thereof, nor any of their employees, makes any warranty, express or implied, or assumes any legal liability or responsibility for the accuracy, completeness, or usefulness of any information, apparatus, product, or process disclosed, or represents that its use would not infringe privately owned rights. Reference herein to any specific commercial product, process, or service by trade name, trademark, manufacturer, or otherwise, does not necessarily constitute or imply its endorsement, recommendation, or favoring by the United States Government or any agency thereof. The views and opinions of authors expressed herein do not necessarily state or reflect those of the United States Government or any agency thereof. 


\title{
BEYOND GUARANTEED SAVINGS: ADDITIONAL COST SAVINGS ASSOCIATED WITH ESPC PROJECTS
}

\author{
John Shonder
}

Date Published: March 2013

\author{
Prepared by \\ OAK RIDGE NATIONAL LABORATORY \\ Oak Ridge, Tennessee 37831-6283 \\ managed by \\ UT-BATTELLE, LLC \\ for the \\ U.S. DEPARTMENT OF ENERGY \\ under contract DE-AC05-00OR22725
}





\section{Contents}

Page

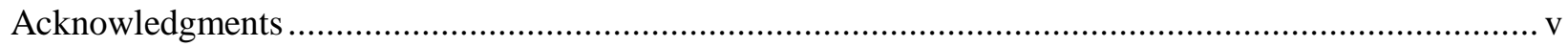

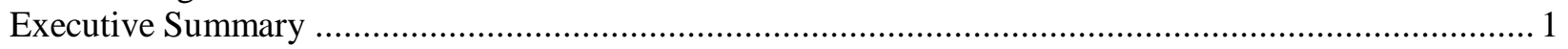

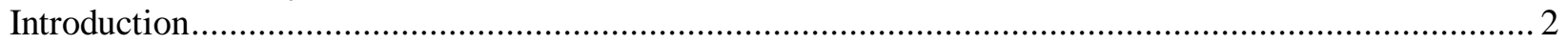

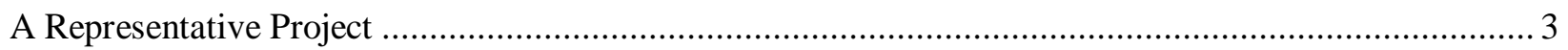

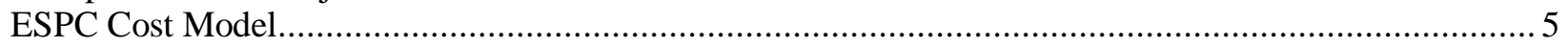

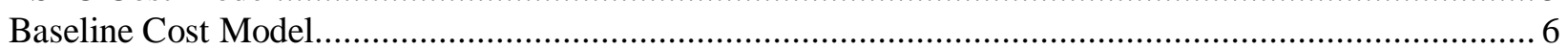

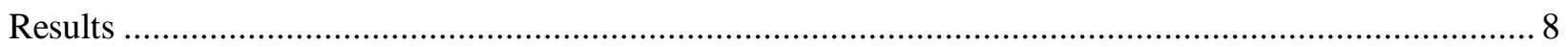

Sensitivity Analysis

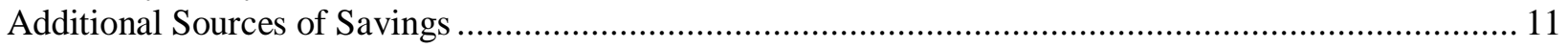

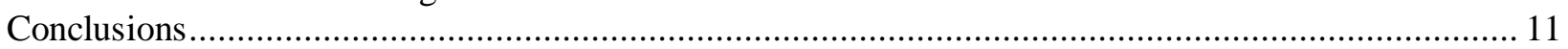

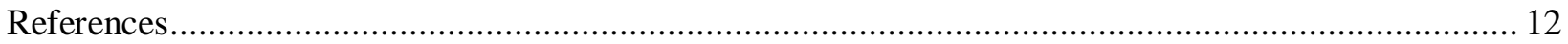





\section{Acknowledgments}

The author would like to thank Dr. Timothy Unruh, Program Manager for the Department of Energy's Federal Energy Management Program, for his valuable guidance and support in preparing this work. 



\section{Beyond Guaranteed Savings: Additional Cost Savings Associated With ESPC Projects}

\section{Executive Summary}

Energy Savings Performance Contract (ESPC) projects are generally believed to deliver only small cost savings to the government, given that most of the guaranteed savings are paid to the Energy Service Company (ESCO). The main conclusion of this report is that significant cost savings do accrue to the government. These savings come about because (1) the ESCO does not guarantee all of the savings it estimates; (2) the useful life of the equipment extends beyond the performance period of the ESPC; (3) National Institutes for Standards and Technology (NIST)/Energy Information Administration projections for energy price escalation have been very conservative with respect to actual price increases; and (4) the baseline case that forms the basis of the guaranteed savings calculation assumes that the baseline equipment would maintain the same efficiency and require the same level of maintenance for a period of time equal to the performance period of the ESPC. More realistic assumptions indicate that for a representative project, the federal government receives nearly twice the level of cost savings guaranteed by the ESCO. Figure 1 presents a breakdown of the sources of these savings.

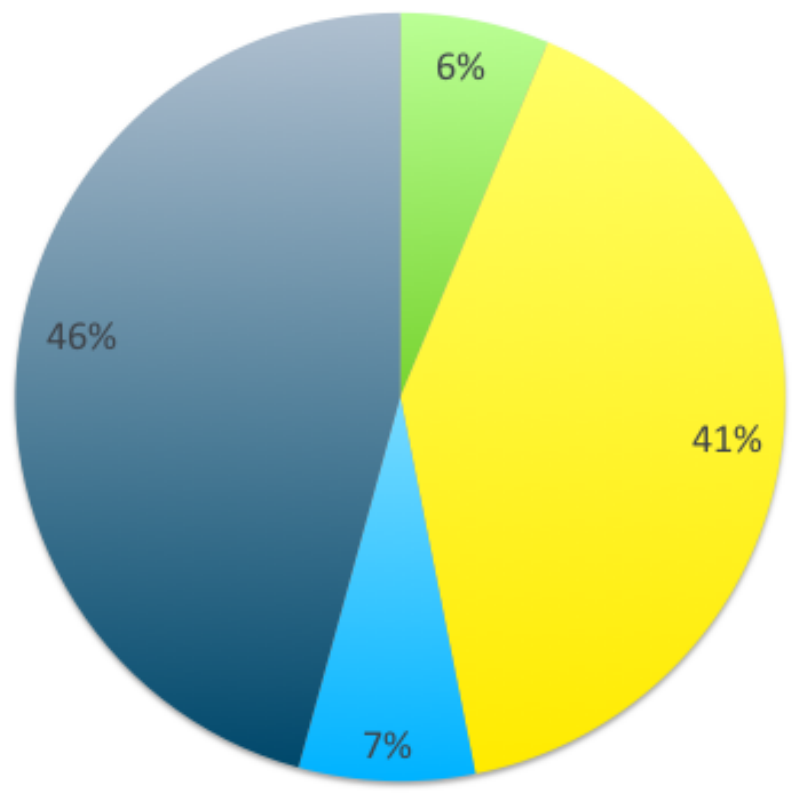

ESCO guaranteeing only $96 \%$ of estimated savings

Savings accruing beyond term

Underestimation of energy escalation rates

Efficiency decay of baseline equipment

Figure 1. Sources of additional cost savings in a representative ESPC project. 


\section{Introduction}

Net cost savings to the government in federal ESPC projects are generally believed to be small, given that most of the guaranteed energy and energy-related cost savings accruing over the life of the contract are paid to the ESCO. However, this belief is based on the assumption that the guaranteed cost savings are more or less equal to the actual avoided costs associated with the project. As shown in this report, there are four principal sources of cost savings that are not captured in the calculation of the guaranteed savings. A methodology is presented for quantifying these additional savings in a representative project.

First, to reduce their risk, ESCOs routinely guarantee only about $96 \%$ of the estimated cost savings from an ESPC project. This means that in the absence of any shortfalls, the site receives about $104 \%$ of the guaranteed savings during the project performance period.

A second source of additional savings is that guaranteed cost savings accrue only during the performance period of an ESPC project. The average performance period in the Federal Energy Management Program's (FEMP) ESPC program is 17 years, and it seems likely that equipment that has been well maintained over 17 years will have additional useful service life at the end of this period. Exactly how much service life remains will depend on the particular equipment involved, but large centrifugal chillers, for example, have a useful service life of greater than 25 years (ASHRAE, 2011).

A third source of additional savings involves the assumed rates of escalation for energy and energy-related savings that are used to calculate contract utility prices in ESPC projects. To determine these escalation rates, agencies and ESCOs have most often used the factors contained in the NIST Annual Supplement to Handbook 135 (NIST, 2013). However, since 1998, these projections have been very conservative (EIA, 2012), meaning that energy prices have increased at a faster rate than these projections assumed. Therefore, the avoided cost of energy and energyrelated $0 \& \mathrm{M}$ is higher than the guaranteed cost savings.

Finally, energy savings in ESPC projects are calculated with respect to a "do nothing" case in which the existing equipment is left in place. The calculation assumes that the existing equipment would have the same performance, and require the same level of maintenance, over the life of the ESPC contract. In reality, however, equipment suitable for replacement in an ESPC is usually nearing the end of its useful service life. Were it to remain in place, its efficiency would likely decrease, and maintenance costs increase, over time. Thus the calculation of savings tends to underestimate the costs associated with the "do nothing" case and consequently underestimates the savings associated with the ESPC.

As shown in the following sections, the additional cost savings that accrue to the government as a result of these four factors are significant. For the representative 
project examined here, the additional cost savings were equal to about $96 \%$ of the guaranteed cost savings, meaning that the total cost savings delivered to the government is about 1.96 times the guaranteed cost savings.

\section{A Representative Project}

The analysis began with the definition of a representative ESPC project, using data on task orders awarded under FEMP's ESPC indefinite delivery, indefinite quality (IDIQ) contract from 2010 through 2012. Over this period, the average project implementation price was approximately \$18.2 million. Implementation price includes all direct project implementation expenses (surveys, feasibility studies, design, equipment, construction, commissioning) plus mark-up to recover indirect costs (overheads, sales effort, etc.) and profit.

An agency planning a comprehensive energy-efficiency retrofit may find that the ESPC project will make planned repair or renewal projects unnecessary because they will be included in or obviated by the ESPC project. The savings from the expenditures avoided because of the project may qualify as a one-time energyrelated cost savings that can be applied as a one-time payment to the ESCO. From 2010 through 2012, one-time payments from savings (excluding projects with large American Recovery and Reinvestment Act payments) averaged about $10 \%$ of project implementation price.

Although the investment-weighted interest rate over the 2010-2012 period was $5.76 \%$, an interest rate of $4 \%$ was chosen for the representative project in order to be consistent with more recent awards. ESPC project interest rates depend on Treasury rates and market conditions, and have been on a general downward trend for the past several years.

In an ESPC project, the ESCO does not receive payments from the government until the government has accepted the conservation measures installed. For this reason, the ESCO must borrow more than the amount required to install the project in order to make interest payments to the financier during the construction period. The amount of overborrowing is called the Finance Procurement Price. In addition to capitalized construction period interest, it may also include payment and performance bonds, closing costs and other fees. For the representative project, the Finance Procurement Price was set equal to 1.78 times the annual interest on the sum of the implementation price and the finance procurement price. This is the average for projects awarded from 2010-2012.

The performance period service price in the first year of the performance period was set equal to $2.15 \%$ of the implementation price, or $\$ 391,300$. Of this amount, $90.7 \%$ is assumed to be for 0\&M and $9.3 \%$ for measurement and verification. According to NIST's current recommendations for general price inflation (NIST, 2013), this figure is assumed to escalate at $2.1 \%$ per year. 
The simple payback for the project was assumed to be 11.6, making the year-1 estimated cost savings equal to $\$ 1,568,966$. This figure is also assumed to escalate at $2.1 \%$ per year according to NIST's projections for electricity price escalation over 17 years (NIST, 2013). The ESCO was assumed to guarantee $96 \%$ of the estimated savings, consistent with the current average for ESPC projects awarded under FEMP's contract (Shonder and Slattery, 2012).

The representative parameters needed for the cost analysis, and based on averages from Task Orders awarded from 2010 through 2012, are summarized in Table 1.

Table 1. Parameters of representative ESPC project

\begin{tabular}{lcc}
\hline Parameter & Value & Escalation rate \\
\hline Implementation price & $\$ 18,200,000$ & - \\
Project interest rate & $4 \%$ & - \\
Finance procurement price & $\$ 1,471,422$ & - \\
One-time payment from savings & $\$ 1,820,000$ & - \\
Year-1 guaranteed cost savings & $\$ 1,568,966$ & $2.1 \%$ \\
$\begin{array}{l}\text { Performance period service price (initial year of } \\
\text { performance period) }\end{array}$ & $\$ 391,300$ & $2.1 \%$ \\
\hline
\end{tabular}

The ESPC was also assumed to conform to the following:

- Two year construction period

- Annual-in-advance payments

- Monthly compounding of interest

- ESCO payment of one dollar less than the guaranteed cost savings

With these assumptions and the parameters of Table 1, the performance period of the representative project is found to be 17 years, which is equal to the current average performance period for ESPC task orders awarded under FEMP's IDIQ contract. The total guaranteed savings is $\$ 34,824,133$.

To study the effects of savings decay, energy price escalation rate, and other parameters, additional assumptions were required regarding the sources of the guaranteed cost savings. First, the project was assumed to represent replacement of chillers with an efficiency of $1 \mathrm{~kW} /$ ton by newer, more efficient chillers with an efficiency of $0.6 \mathrm{~kW} /$ ton. The site's $0 \& \mathrm{M}$ cost for the baseline equipment was assumed to be $50 \%$ of the ESCO's O\&M costs in any given year. In the first year of the performance period, the ESCO's cost to maintain the new chillers is (0.907) $\times$ $\$ 391,300=\$ 354,909$, so it is assumed that the site's cost to maintain the baseline chillers would be half this amount, or $\$ 177,455$. Given the $0 \& M$ escalation rate of $2.1 \%$, the site's year- $10 \& M$ costs for the baseline chillers is $\$ 170,230$. This amount is claimed as energy-related O\&M savings in the ESPC. 
Then, with an electricity price of 9 cents per kWh, an annual cooling load of 488,036 MMBtu gives year- 1 electricity cost savings of $\$ 1,464,109$. Adding the energyrelated $0 \& M$ savings gives a total year- 1 estimated savings of $\$ 1,634,339$. With the ESCO guaranteeing $96 \%$ of this amount, year-1 guaranteed cost savings are $\$ 1,568,966$, exactly the amount in Table 1 .

Given the annual cooling load and the baseline and post-retrofit efficiencies, the annual energy savings for the representative project is $16,267,881 \mathrm{kWh}$ or 61,960 MMBtu, giving an annual savings of 3,050 Btu per dollar invested. The average for projects awarded under FEMP's ESPC program from 2010 through 2012 was 3,928 Btu per dollar invested, but the figure of 3,050 BTU per dollar invested is well within the range of figures for individual projects.

To determine savings, two cost models were developed: one for the ESPC case and another for a baseline case in which the baseline equipment is left in place. The study period for both cases is 25 years.

\section{ESPC Cost Model}

The cost model for the ESPC case includes the following costs:

- Payments made to the ESCO for debt service, O\&M on the installed chillers and M\&V costs during the 17-year project term

- Payments to the utility for electricity to operate the replacement chillers

- O\&M costs paid by the site after the completion of the ESPC (years 18-25)

Upon completion of the ESPC, the efficiency of the chillers is assumed to decay by $1 \%$ per year to account for the reduced level of maintenance performed by the site compared with maintenance by the ESCO. A $1 \%$ rate of decay has been used in previous ORNL reports (Hughes et al., 2003; Shonder et al., 2006) and in reports by others (Hopper et al., 2005; GAO, 2005). The cost to the site for this reduced level of maintenance is $50 \%$ of what the ESCO's O\&M cost would have been in any given year.

While NIST's projection sets the escalation rate for electricity cost savings at $2.1 \%$, the price of commercial electricity has actually risen by about $2.5 \%$ per year since 1998 (EIA, 2013). To calculate electricity costs, the ESPC model assumes electricity prices escalate at $2.5 \%$ per year from the baseline cost of $\$ 0.09$ per $\mathrm{kWh}$. The guaranteed savings escalates at the more conservative rate of $2.1 \%$.

Table 2 presents the costs for each year of the ESPC case. Note that the one-time payment from savings of $\$ 1,820,000$ is included in the guaranteed savings for the initial year of the performance period. Construction is assumed to begin in year 1 , and there is a 2 year construction period. Year 1 is not included in Table 2. 


\section{Baseline Cost Model}

The baseline model assumes the site leaves the existing chillers in place for the 25year study period, and accounts for the cost of electricity and 0\&M on these chillers. As with the ESPC case, electricity prices are assumed to escalate at the more realistic rate of $2.5 \%$ per year. It is also assumed that the site's $0 \& \mathrm{M}$ costs in the baseline case are one-half of the ESCO's costs to maintain the new chillers, at least initially. However, unlike in the standard ESPC analysis, here it is assumed that the site's $0 \& \mathrm{M}$ costs increase by $1 \%$ per year above inflation to account for the equipment degradation caused by the reduced level of maintenance. Furthermore, the site's reduced level of maintenance is assumed to result in a decay of $1 \%$ per year in the efficiency of the baseline chillers.

Table 3 presents the costs for the baseline case. Note that the $\$ 1,820,000$ that appears as a one-time payment in the ESPC case shows up here as a one-time O\&M cost in year 3. A one-time cost to repair the baseline chillers would be a legitimate source for a one-time payment from savings in the ESPC, since the ESPC would eliminate the need to repair the baseline chillers. 
Table 2. Costs for ESPC case

\begin{tabular}{|c|c|c|c|c|c|c|c|c|c|c|}
\hline Year & $\begin{array}{l}\text { Electric use } \\
\quad(\mathrm{kWh})\end{array}$ & $\begin{array}{l}\text { Electric } \\
\text { price } \\
(\$ / \mathrm{kWh})\end{array}$ & $\begin{array}{l}\text { Electric } \\
\text { cost } \\
(\$)\end{array}$ & $\begin{array}{l}\text { Guaranteed } \\
\text { savings } \\
(\$)\end{array}$ & $\begin{array}{l}\text { Performance } \\
\text { period } \\
\text { services } \\
(\$)\end{array}$ & $\begin{array}{l}\text { Interest } \\
\text { payment } \\
(\$)\end{array}$ & $\begin{array}{l}\text { Principal } \\
\text { payment } \\
(\$)\end{array}$ & $\begin{array}{c}\text { ESCO } \\
\text { payment } \\
(\$)\end{array}$ & $\begin{array}{l}\text { Loan } \\
\text { balance } \\
\text { (\$) }\end{array}$ & $\begin{array}{c}\text { Total } \\
\text { payments } \\
(\$)\end{array}$ \\
\hline 2 & & & & & & & & & $19,595,177$ & \\
\hline 3 & $24,401,821$ & 0.09 & $2,307,345$ & $3,455,554$ & 391,300 & 65,317 & $2,998,936$ & $3,455,553$ & $16,596,241$ & $5,762,898$ \\
\hline 4 & $24,401,821$ & 0.10 & $2,365,028$ & $1,669,901$ & 399,517 & 676,156 & 594,226 & $1,669,900$ & $16,002,015$ & $4,034,928$ \\
\hline 5 & $24,401,821$ & 0.10 & $2,424,154$ & $1,704,969$ & 407,907 & 651,947 & 645,114 & $1,704,968$ & $15,356,901$ & $4,129,122$ \\
\hline 6 & $24,401,821$ & 0.10 & $2,484,758$ & $1,740,773$ & 416,473 & 625,664 & 698,635 & $1,740,772$ & $14,658,267$ & $4,225,530$ \\
\hline 7 & $24,401,821$ & 0.10 & $2,546,877$ & $1,777,329$ & 425,219 & 597,200 & 754,909 & $1,777,328$ & $13,903,358$ & $4,324,205$ \\
\hline 8 & $24,401,821$ & 0.11 & $2,610,549$ & $1,814,653$ & 434,149 & 566,444 & 814,059 & $1,814,652$ & $13,089,299$ & $4,425,201$ \\
\hline 9 & $24,401,821$ & 0.11 & $2,675,812$ & $1,852,761$ & 443,266 & 533,278 & 876,216 & $1,852,760$ & $12,213,083$ & $4,528,572$ \\
\hline 10 & $24,401,821$ & 0.11 & $2,742,708$ & $1,891,669$ & 452,574 & 497,580 & 941,513 & $1,891,668$ & $11,271,570$ & $4,634,375$ \\
\hline 11 & $24,401,821$ & 0.12 & $2,811,275$ & $1,931,394$ & 462,079 & 459,221 & $1,010,093$ & $1,931,393$ & $10,261,477$ & $4,742,668$ \\
\hline 12 & $24,401,821$ & 0.12 & $2,881,557$ & $1,971,953$ & 471,782 & 418,068 & $1,082,101$ & $1,971,952$ & $9,179,376$ & $4,853,509$ \\
\hline 13 & $24,401,821$ & 0.12 & $2,953,596$ & $2,013,364$ & 481,690 & 373,982 & $1,157,691$ & $2,013,363$ & $8,021,684$ & $4,966,959$ \\
\hline 14 & $24,401,821$ & 0.12 & $3,027,436$ & $2,055,645$ & 491,805 & 326,816 & $1,237,023$ & $2,055,644$ & $6,784,661$ & $5,083,080$ \\
\hline 15 & $24,401,821$ & 0.13 & $3,103,122$ & $2,098,813$ & 502,133 & 276,418 & $1,320,262$ & $2,098,812$ & $5,464,400$ & $5,201,934$ \\
\hline 16 & $24,401,821$ & 0.13 & $3,180,700$ & $2,142,888$ & 512,678 & 222,628 & $1,407,581$ & $2,142,887$ & $4,056,818$ & $5,323,587$ \\
\hline 17 & $24,401,821$ & 0.13 & $3,260,218$ & $2,187,889$ & 523,444 & 165,281 & $1,499,163$ & $2,187,888$ & $2,557,655$ & $5,448,106$ \\
\hline 18 & $24,401,821$ & 0.14 & $3,341,723$ & $2,233,835$ & 534,436 & 104,203 & $1,595,194$ & $2,233,834$ & 962,461 & $5,575,557$ \\
\hline 19 & $24,401,821$ & 0.14 & $3,425,266$ & $2,280,745$ & 545,660 & 39,212 & 962,461 & $1,547,333$ & 0 & $4,972,599$ \\
\hline 20 & $24,401,821$ & 0.14 & $3,510,898$ & $2,328,641$ & 557,118 & 0 & 0 & 0 & 0 & $3,763,551$ \\
\hline 21 & $24,648,304$ & 0.15 & $3,635,020$ & $2,377,542$ & 568,818 & 0 & 0 & 0 & 0 & $3,895,559$ \\
\hline 22 & $24,897,277$ & 0.15 & $3,763,531$ & $2,427,471$ & 580,763 & 0 & 0 & 0 & 0 & $4,032,201$ \\
\hline 23 & $25,148,764$ & 0.15 & $3,896,585$ & $2,478,448$ & 592,959 & 0 & 0 & 0 & 0 & $4,173,640$ \\
\hline 24 & $25,402,792$ & 0.16 & $4,034,343$ & $2,530,495$ & 605,411 & 0 & 0 & 0 & 0 & $4,320,045$ \\
\hline 25 & $25,659,386$ & 0.16 & $4,176,972$ & $2,583,635$ & 18,125 & 0 & 0 & 0 & 0 & $4,471,590$ \\
\hline
\end{tabular}


Table 3. Costs for the baseline case

\begin{tabular}{|c|c|c|c|c|c|c|c|}
\hline Year & EER & Electric use (kWh) & $\begin{array}{c}\text { Electric } \\
\text { price }(\$ / \mathrm{kWh})\end{array}$ & $\begin{array}{c}\text { Electric } \\
\text { cost } \\
(\$)\end{array}$ & $\begin{array}{c}0 \& M \text { costs } \\
(\$)\end{array}$ & $\begin{array}{l}\text { One-time } \\
\text { O\&M cost } \\
(\$)\end{array}$ & $\begin{array}{l}\text { Total payments } \\
\qquad \$(\$)\end{array}$ \\
\hline \multicolumn{8}{|l|}{1} \\
\hline \multicolumn{8}{|l|}{2} \\
\hline 3 & 12.0 & $40,669,702$ & 0.09 & $3,845,574$ & 177,455 & $1,820,000$ & $5,843,029$ \\
\hline 4 & 11.9 & $41,080,507$ & 0.10 & $3,981,529$ & 182,993 & 0 & $4,164,522$ \\
\hline 5 & 11.8 & $41,495,461$ & 0.10 & $4,122,290$ & 188,704 & 0 & $4,310,994$ \\
\hline 6 & 11.6 & $41,914,607$ & 0.10 & $4,268,028$ & 194,594 & 0 & $4,462,621$ \\
\hline 7 & 11.5 & $42,337,987$ & 0.10 & $4,418,918$ & 200,667 & 0 & $4,619,584$ \\
\hline 8 & 11.4 & $42,765,644$ & 0.11 & $4,575,142$ & 206,930 & 0 & $4,782,072$ \\
\hline 9 & 11.3 & $43,197,620$ & 0.11 & $4,736,889$ & 213,388 & 0 & $4,950,277$ \\
\hline 10 & 11.2 & $43,633,959$ & 0.11 & $4,904,355$ & 220,048 & 0 & $5,124,403$ \\
\hline 11 & 11.1 & $44,074,706$ & 0.12 & $5,077,742$ & 226,915 & 0 & $5,304,657$ \\
\hline 12 & 11.0 & $44,519,905$ & 0.12 & $5,257,258$ & 233,997 & 0 & $5,491,255$ \\
\hline 13 & 10.9 & $44,969,601$ & 0.12 & $5,443,120$ & 241,301 & 0 & $5,684,421$ \\
\hline 14 & 10.7 & $45,423,840$ & 0.12 & $5,635,554$ & 248,832 & 0 & $5,884,385$ \\
\hline 15 & 10.6 & $45,882,667$ & 0.13 & $5,834,791$ & 256,598 & 0 & $6,091,388$ \\
\hline 16 & 10.5 & $46,346,128$ & 0.13 & $6,041,071$ & 264,606 & 0 & $6,305,677$ \\
\hline 17 & 10.4 & $46,814,271$ & 0.13 & $6,254,644$ & 272,864 & 0 & $6,527,509$ \\
\hline 18 & 10.3 & $47,287,142$ & 0.14 & $6,475,768$ & 281,380 & 0 & $6,757,149$ \\
\hline 19 & 10.2 & $47,764,790$ & 0.14 & $6,704,709$ & 290,162 & 0 & $6,994,872$ \\
\hline 20 & 10.1 & $48,247,262$ & 0.14 & $6,941,745$ & 299,218 & 0 & $7,240,963$ \\
\hline 21 & 10.0 & $48,734,609$ & 0.15 & $7,187,160$ & 308,557 & 0 & $7,495,717$ \\
\hline 22 & 9.9 & $49,226,877$ & 0.15 & $7,441,251$ & 318,187 & 0 & $7,759,438$ \\
\hline 23 & 9.8 & $49,724,119$ & 0.15 & $7,704,326$ & 328,118 & 0 & $8,032,443$ \\
\hline 24 & 9.7 & $50,226,382$ & 0.16 & $7,976,701$ & 338,358 & 0 & $8,315,059$ \\
\hline 25 & 9.6 & $50,733,720$ & 0.16 & $8,258,706$ & 348,918 & 0 & $8,607,624$ \\
\hline
\end{tabular}

\section{Results}

Table 4 compares the costs in the ESPC and baseline cases, with the savings defined as the baseline costs minus the ESPC costs. It is seen that the net cost savings over the 25 year study period is $\$ 33,860,000$. This is $97 \%$ of the guaranteed savings. Another way of stating the result is that the ESPC project results in cost savings to the agency of 1.97 times the guaranteed cost savings. Nearly all of the guaranteed cost savings is paid to the ESCO, leaving the agency a net cost savings of about $97 \%$ of the guaranteed savings. 
Table 4. Comparison of ESPC and baseline cases (\$)

\begin{tabular}{rrrrr}
\hline Year & \multicolumn{1}{c}{$\begin{array}{c}\text { Total } \\
\text { payments, } \\
\text { ESPC case }\end{array}$} & $\begin{array}{c}\text { Total } \\
\text { payments, } \\
\text { baseline case }\end{array}$ & \multicolumn{1}{l}{ Savings } & \multicolumn{1}{c}{$\begin{array}{c}\text { Present value } \\
\text { of savings }\end{array}$} \\
\hline 1 & & & & \\
2 & & & & \\
3 & $5,762,898$ & $5,843,029$ & 80,131 & 75,752 \\
4 & $4,034,928$ & $4,164,522$ & 129,594 & 119,117 \\
5 & $4,129,122$ & $4,310,994$ & 181,873 & 162,536 \\
6 & $4,225,530$ & $4,462,621$ & 237,092 & 206,013 \\
7 & $4,324,205$ & $4,619,584$ & 295,380 & 249,548 \\
8 & $4,425,201$ & $4,782,072$ & 356,871 & 293,144 \\
9 & $4,528,572$ & $4,950,277$ & 421,705 & 336,802 \\
10 & $4,634,375$ & $5,124,403$ & 490,028 & 380,524 \\
11 & $4,742,668$ & $5,304,657$ & 561,989 & 424,311 \\
12 & $4,853,509$ & $5,491,255$ & 637,746 & 468,167 \\
13 & $4,966,959$ & $5,684,421$ & 717,462 & 512,091 \\
14 & $5,083,080$ & $5,884,385$ & 801,306 & 556,086 \\
15 & $5,201,934$ & $6,091,388$ & 889,454 & 600,155 \\
16 & $5,323,587$ & $6,305,677$ & 982,090 & 644,298 \\
17 & $5,448,106$ & $6,527,509$ & $1,079,403$ & 688,517 \\
18 & $5,575,557$ & $6,757,149$ & $1,181,592$ & 732,815 \\
19 & $4,972,599$ & $6,994,872$ & $2,022,273$ & $1,219,446$ \\
20 & $3,763,551$ & $7,240,963$ & $3,477,412$ & $2,038,799$ \\
21 & $3,895,559$ & $7,495,717$ & $3,600,158$ & $2,052,275$ \\
22 & $4,032,201$ & $7,759,438$ & $3,727,237$ & $2,065,841$ \\
23 & $4,173,640$ & $8,032,443$ & $3,858,803$ & $2,079,496$ \\
24 & $4,320,045$ & $8,315,059$ & $3,995,014$ & $2,093,242$ \\
25 & $4,471,590$ & $8,607,624$ & $4,136,033$ & $2,107,080$ \\
\hline Total & $\mathbf{1 0 6 , 8 8 9 , 4 1 7}$ & $\mathbf{1 4 0 , 7 5 0 , 0 6 0}$ & $\mathbf{3 3 , 8 6 0 , 6 4 3}$ & $\mathbf{2 0 , 1 0 6 , 0 5 5}$ \\
\hline & & & & \\
\hline
\end{tabular}

For 2013, the Office of Management and Budget specifies a nominal discount rate of $2.85 \%$ for 25 year analyses (OMB, 2013). Given this discount rate, the present value of the savings is $\$ 20,106,055$.

As stated in the introduction, there are four principal factors that account for the net cost savings:

1. The ESCO does not guarantee all of the estimated savings.

2. Additional savings accrue beyond the performance period.

3. NIST's recommended escalation rates for energy savings have consistently underestimated the actual escalation of energy prices. 
4. Estimated savings in ESPCs are based on the assumption that the baseline equipment would maintain the same performance and incur the same 0\&M costs for a period equal to the length of the ESPC performance period.

To determine the relative effect of each of these factors, the spreadsheet model was used to relax each of the four sequentially. Table 5 presents the results. The last column shows the relative effect of relaxing each of the four factors in turn. In other words, accounting for the fact that the ESCO guarantees only $96 \%$ of the savings increases the net savings by $6.1 \%$ of the guaranteed savings. Accounting for the additional savings that accrue beyond the performance period increases net savings by an additional $39.5 \%$ of the guaranteed savings. Accounting for the actual increase in energy prices increases net savings by an additional $7.2 \%$ of the guaranteed savings. And finally, accounting for modest decay in the performance of the baseline equipment due to the reduced level of maintenance performed by the site increases net savings by an additional $44.5 \%$ of the guaranteed savings.

Table 5. Net savings from relaxing assumptions 1 through 4

\begin{tabular}{rrr}
\hline Assumptions & Net savings & Percentage \\
\hline 1 & $\$ 2,108,601$ & $6.1 \%$ \\
$1+2$ & $\$ 15,850,657$ & $39.5 \%$ \\
$1+2+3$ & $\$ 18,356,059$ & $7.2 \%$ \\
$1+2+3+4$ & $\$ 33,860,643$ & $44.5 \%$ \\
\hline
\end{tabular}

\section{Sensitivity Analysis}

The net cost savings calculated above depends on the following assumed parameter values:

- efficiency decay rate: $1 \%$

- actual energy escalation rate: $2.5 \%$

- $0 \& M$ cost escalation rate: $1 \%$

- site's O\&M as a percentage of the ESCO's costs: $50 \%$

Table 6 shows how the net cost savings change when the values of these parameters are decreased and increased by $10 \%$ of their assumed values. It is seen that changing the parameters by $\pm 10 \%$ changes the net savings by $1-7 \%$. 
Table 6. Net cost savings with parameter values $10 \%$ lower and $10 \%$ higher than the assumed values

\begin{tabular}{lll}
\hline Parameter & $-10 \%$ & $+10 \%$ \\
\hline Efficiency decay rate (1\%) & $\$ 32,253,165$ & $\$ 35,496,581$ \\
Actual energy escalation rate (2.5\%) & $\$ 31,651,315$ & $\$ 36,161,756$ \\
O\&M cost escalation rate (1\%) & $\$ 33,793,969$ & $\$ 33,928,353$ \\
Site's O\&M as a percent of ESCO's costs & & \\
$(50 \%)$ & $\$ 34,160,313$ & $\$ 33,560,973$ \\
\hline
\end{tabular}

One parameter not included in Table 6 is the useful service life of the equipment. The representative project installed equipment with a service life of 25 years, giving it 6 years of additional service life after the completion of the ESPC contract. Other equipment might not have the same life. If the equipment has only 4 years of service life upon the completion of the ESPC contract, the net savings falls to $\$ 25,729,596$. This means that a reasonable range for the total savings to the government is between $174 \%$ and $197 \%$ of the guaranteed savings. Clearly the net savings is most sensitive to the assumed service life of the replacement equipment.

\section{Additional Sources of Savings}

This report did not consider all potential sources of additional savings. For example, energy savings in ESPC projects are usually calculated on the basis of weather conditions for a typical year at the site. Actual weather that is more severe would result in additional savings. In the representative project, higher cooling loads would result in longer run hours and thus higher electricity savings when the baseline chillers are compared with the replacement chillers. Additional savings of this nature would depend on the particular site and its weather conditions, and would be difficult to estimate for a representative project.

Another potential source of savings is increased productivity in buildings that receive upgrades, compared with buildings in the baseline case. Case studies have documented increases in worker productivity in energy-efficient buildings. But the data are sparse. A 2003 meta-study analyzed a number of previous studies and found increased productivity due to a number of factors, including improved lighting, quieter working conditions, and improved ventilation (Loftness et al., 2003). Productivity gains in most cases were in the range of a few percent. Changes at this level would have only a small effect on the conclusions of this report.

\section{Conclusions}

The objective of this report was to develop a reasonable estimate for the additional savings that accrue to the government in an ESPC project beyond the guaranteed savings. A representative ESPC project was chosen based on data from FEMP's ESPC 
program from 2010 through 2012, and cost models were developed of both the ESPC case and the baseline case. To account for escalation of energy prices beyond the value NIST recommends, electricity prices in both cases were escalated at a rate corresponding to the actual rate of price inflation for 1998-2012, while guaranteed savings were escalated at the value recommended by NIST. To account for the lower level of maintenance provided by government sites compared with the ESCO, the efficiency of the baseline equipment was assumed to decay at $1 \%$ per year, a rate that has been used in previous studies. To account for the effects of this lower level of maintenance on equipment degradation, costs for 0\&M performed by the site were assumed to increase by $1 \%$ per year.

Given these assumptions for the representative project, the total cost savings to the government was found to be 1.97 times the guaranteed savings. Nearly all of the guaranteed cost savings is paid to the ESCO, leaving the agency a net cost savings of about $97 \%$ of the guaranteed savings.

Two key assumptions made in the analysis are that the baseline equipment remains in place for 25 years and that the replacement equipment has a useful service life of 25 years. Although the latter assumption seems more likely than the former, it is possible that both the baseline and the replacement equipment would require replacement sometime before the end of 25 years. Since the cost of replacement would be similar in each case, the net savings as estimated by this analysis would not change by a significant amount.

The main conclusion of this report is that significant cost savings do accrue to the government in ESPC projects, despite the fact that most of the guaranteed savings is paid to the ESCO during the performance period. This savings comes about because (1) the ESCO does not guarantee all of the savings it estimates; (2) the useful life of the equipment extends beyond the performance period of the ESPC; (3) NIST/EIA projections for energy price escalation have been very conservative with respect to actual price increases; and (4) the baseline case that forms the basis of the guaranteed savings calculation assumes that the baseline equipment would maintain the same efficiency and require the same level of maintenance for a period of time equal to the performance period of the ESPC. More realistic assumptions indicate that the federal government actually receives nearly twice the level of guaranteed savings for a representative project.

\section{References}

ASHRAE 2011. HVAC Applications: Owning and Operating Costs (Ch. 37). American Society of Heating, Refrigerating and Air Conditioning Engineers, Inc. Atlanta.

EIA 2013. Average Electricity Price by State by Provider, Back to 1990 (Form EIA861) http://www.eia.gov/electricity/data/state/avgprice annual.xls. US Energy Information Agency. 
GAO 2005. Performance Contracts Offer Benefits, but Vigilance Is Needed to Protect Government Interests (http://www.gao.gov/new.items/d05340.pdf). US Government Accountability Office.

Hopper, N., C. Goldman, J. McWilliams, D. Birr, Stoughton K. McMordie 2005. Public and Institutional Markets for ESCO Services: Comparing Programs, Practices and Performance. LBNL-55002. Ernest Orlando Lawrence Berkeley National Laboratory (http://eetd.lbl.gov/EA/EMp/reports/55002.pdf).

Hughes, P., J. Shonder, T. Sharp, M. Madgett 2003. Evaluation of Federal Energy Savings Performance Contracting: Methodology for Comparing Processes and Costs of ESPC and Appropriations-Funded Energy Projects. ORNL/TM-2002/150. Oak Ridge National Laboratory.

Loftness, V., V. Hartkopf, B. Gurtekin, D. Hansen, R. Hitchcock 2003. “Linking Energy to Health and Productivity in the Built Environment." Center for Building Performance and Diagnostics, Carnegie Mellon. 2003 Greenbuild Conference, Pittsburgh, Pennsylvania, November 12-14, 2003.

NIST 2013. Energy Escalation Rate Calculator version 2.0-12 for Windows http://www1.eere.energy.gov/femp/information/eerc download.html.

OMB 2013. Circular A-94 Appendix C, Revised December 2012. http://www.whitehouse.gov/omb/circulars a094/a94 appx-c. Office of Management and Budget.

Shonder, J., P. Hughes, E. Atkin 2006. Comparing Life-Cycle Costs of ESPCs and Appropriations-Funded Energy Projects: An Update to the 2002 Report. ORNL/TM2006/138. Oak Ridge National Laboratory.

Shonder, J. and B. Slattery 2012. Reported Energy and Cost Savings from the DOE ESPC Program, ORNL/TM-2012. Oak Ridge National Laboratory. 